\title{
CHEMICAL COMPOSITION, ANTIMICROBIAL AND ANTIOXIDANT ACTIVITY OF THE ESSENTIAL OIL OF LEAVES OF Eugenia involucrata DC.
}

\author{
COMPOSIÇÃO QUÍMICA, ATIVIDADE ANTIMICROBIANA E ANTIOXIDANTE DO \\ ÓLEO ESSENCIAL DAS FOLHAS DE Eugenia involucrata DC.
}

\author{
Adrieli Gorlin TOLEDO'; Juliete Gomes de Lara de SOUZA ; Jéssica Patrícia Borges da SILVA²; \\ Wagner Alex Jann FAVRETO³ ${ }^{3}$ Willian Ferreira da COSTA ${ }^{3}$; Fabiana Gisele da Silva PINTO ${ }^{*}$ \\ 1. Program of Conservation and Management of Natural Resources, Biotechnology Laboratory, West of Paraná State University \\ (UNIOESTE), Cascavel, Paraná, Brazil; 2. Herbarium, Conservation and Management of Natural Resources Program, State University \\ of the West of Paraná - UNIOESTE; 3. Department of Chemistry, Maringá, State University of Maringá - UEM. \\ *fabiana.pinto@unioeste.br
}

\begin{abstract}
In the Myrtaceae family, the species Eugenia involucrata DC., popularly known as "cerejeira-do-mato", is traditionally used for the antidiarrheal and digestive action of its leaves. However, no studies were found in the literature regarding its antimicrobial and antioxidant potential. In this context, the objective of the present study was to determine the chemical composition by gas chromatography coupled to mass spectrometry (GC-MS) to evaluate the antimicrobial activity by the broth microdilution technique and the antioxidant activity by the 2,2-diphenyl-1-picryl-hydrazila (DPPH) method of the essential oil of E. involucrata leaves. GC-MS identified 28 compounds, all sesquiterpenes, corresponding to $89.41 \%$ of the essential oil. The antimicrobial activity of the essential oil was observed for all Gram-positive bacteria tested (Staplylococcus epidermidis, Enterococcus faecalis, Bacillus subtilis and Staplylococcus aureus) and for yeast Candida albicans. The essential oil presented a reduction capacity of DPPH up to $66.81 \%$, evidencing its antioxidant potential. It is suggested that the antimicrobial and antioxidant action of E. involucrata essential oil is related to the presence of the major compounds, elixene (26.53\%), $\beta$-caryophyllene $(13.16 \%), \alpha$-copaene $(8.41 \%)$ and germacrene D $(7.17 \%)$.
\end{abstract}

KEYWORDS: Myrtaceae. Natural products. Volatile compounds. Hydrodistillation. Biological activities. GC-SM.

\section{INTRODUCTION}

The composition of food associated with inadequate processing and storage practices provides ideal conditions for the development of pathogenic microorganisms (FRUTUOSO et al., 2013). These pathogens, once ingested via contaminated food, are a major food safety concern and represent a growing problem in public health (SANTOS et al., 2017). Moreover, the occurrence of a substantial increase of strains with a genetic capacity to acquire and transfer resistance to current antimicrobials has made therapeutic treatment difficult, boosting the pharmaceutical and food industry in the search for alternative antimicrobials (SILVA; FERNANDES JÚNIOR, 2010).

Another factor is a greater demand for "green" products by the consumer, which led to the need to replace chemical additives, with the aim of achieving new preservatives for safer foods (TONGNUANCHAN; SOOTTAWAT, 2014). In addition, naturally occurring antioxidants have gained popularity in the food industry, since synthetic antioxidants, although widely used in food processing, have been questioned with regards to their toxicity to the body (PANIGRAHY; KUMAR; BHATT, 2017). In view of this, natural products, such as plant essential oils, are strong candidates for indication of use in the industry. In addition to their antimicrobial and antioxidant action, they present characteristics that allow a delay in the deterioration and an improvement of the organoleptic quality of the foods.

The species Eugenia involucrata DC. (cerejeira-do-mato) is a Brazilian native plant belonging to the Myrtaceae family, known in traditional medicine for its health benefits. Its leaves are employed in the form of teas, with antidiarrheal and digestive actions (SAUSEN et al., 2009). Research with this genus revealed its therapeutic importance, with antimicrobial and antioxidant activities reported in some species, such as Eugenia caryophyllata (SILVESTRI et al., 2010) and Eugenia jambolana (HAJOORI et al., 2013). However, studies of the antimicrobial and antioxidant activities of the essential oil of $E$. involucrata leaves are scarce. Studies related to the chemical composition of E. involucrata essential oil 
revealed the presence of sesquiterpenes, representing more than $90 \%$ of the constituents (CIARLINI; MARANGONI; BOLZAN， 2017; HENRIQUES et al., 1993; MARIN et al., 2008; RAMOS et al., 2006).

Thus, the objectives of the present study were: (1) determine the chemical composition of the essential oil of $E$. involucrata leaves by gas chromatography coupled to mass spectrometry (GCMS); (2) to evaluate the antimicrobial activity by the broth microdilution technique and (3) to evaluate the antioxidant potential by the 2,2-diphenyl-1picrylhydrazyl (DPPH) method.

\section{MATERIAL AND METHODS}

\section{Collection and identification of plant material}

The collection of the leaves of $E$. involucrata was carried out in the ecological park Paulo Gorski, located in the municipality of Cascavel in the western region of the state of Paraná, between October 2016 and March 2017. The geographic location was determined using the Global Positioning System as follows: $24^{\circ}$ 57'51,4" S $53^{\circ} 26^{\prime} 00,9^{\prime \prime} \mathrm{W}$. The sample of the botanical material was sent for identification by the Herbarium of the State University of the West of Paraná (UNIOESTE) and deposited under number 1650 for registration of the voucher.

\section{Extraction of essential oil}

The leaves were oven dried with air circulation at $40{ }^{\circ} \mathrm{C}$ for between 48 and $72 \mathrm{~h}$. Grinding was achieved using a knife mill, with a $0.42 \mathrm{~mm}$ granulometry membrane. From the dry and milled sample, distilled water was added in the ratio of $1: 10(\mathrm{w} / \mathrm{v})$ and the sample was subjected to the hydrodistillation method for $4 \mathrm{~h}$ using a Clevengertype apparatus (WEBER et al. 2014).

The percentage of essential oil yield (\%) was calculated by: $\%=E O(w) / V M(w) \times 100$, where $E O$ is the total extracted essential oil $(w)$ and $V M$ is dry and ground vegetable mass (w). Subsequently, the samples were stored in conical bottom tubes wrapped in foil, under light and refrigeration, at an average temperature of $4{ }^{\circ} \mathrm{C}$ until the tests were carried out.

\section{Chemical analysis of essential oil}

The analysis of the constituents of $E$. involucrata essential oil was performed from the Thermo-Finnigan GC-MS system by the Gas Chromatography coupled to Mass Spectrometry Laboratory, from the State University of Maringá (UEM), Paraná, Brazil. This system consists of a
GC FOCUS (Thermo Electron), coupled to a DSQ II mass spectrometer (Thermo Electron) and a TriPlus AS automatic injector (Thermo Electron). Chromatographic separation was performed with a HP-5ms fused silica capillary column (30 m long, 0.25 and $0.25 \mu \mathrm{m}$ ID of the film, $5 \%$ phenyl-95\% dimethylpolysiloxane composition). The temperature of the injector was $250{ }^{\circ} \mathrm{C}$. The sample and the alkane standards C7-C28 were injected at a split-ratio of 1:25. The programming of the temperature used was $50{ }^{\circ} \mathrm{C}$ maintained for $2 \mathrm{~min}$, a temperature rise to $180^{\circ} \mathrm{C}$ at a ratio of $2{ }^{\circ} \mathrm{C} \mathrm{min}{ }^{-1}$, followed by an increase to $290{ }^{\circ} \mathrm{C}$ at a ratio of $5^{\circ} \mathrm{C}$ $\mathrm{min}^{-1}$. The interface between the GC and MS was maintained at $270{ }^{\circ} \mathrm{C}$ and the temperature of the ionization source of the mass spectrometer was 250 ${ }^{\circ} \mathrm{C}$. The identification of the compounds was accomplished by comparing their retention times with the retention times obtained from the literature and through their retention indices (ADAMS, 2007; BABUSHOK; LINSTROM; ZENKEVICHB, 2011; YU et al., 2007).

\section{Microorganisms used}

The essential oil was tested against the strains of the American Type Culture Collection (ATCC) and Cefar Diagnóstica Cultures Collection (CCCD), with six Gram-negative strains: Escherichia coli (ATCC 25922), Salmonella enterica Enteritidis (ATCC 13076), Salmonella enterica Typhimurium (ATCC 14028), Pseudomonas aeruginosa (ATCC 27853), Proteus mirabilis (ATCC 25933) and Klebsiella pneumoniae (ATCC 13883); four Gram-positive: Staphylococcus aureus (ATCC 25923), Enterococcus faecalis (ATCC 19433), Staphylococcus epidermidis (ATCC 12228) and Bacillus subtilis subsp. spizizenii (CCCD B005); and a yeast Candida albicans (ATCC 10231).

\section{Antimicrobial activity}

The microorganisms were recovered in a Brain Heart Infusion enrichment broth and incubated for $24 \mathrm{~h}$ at $36 \pm 0.1{ }^{\circ} \mathrm{C}$. After this period, the strains were harvested in a Muller-Hinton (MH) agar medium and incubated for $24 \mathrm{~h}$ at $36 \pm 0.1^{\circ} \mathrm{C}$. To standardize the inoculum, the strains were diluted in saline solution $(0.85 \%)$, resulting in a final concentration of $1 \times 10^{5} \mathrm{CFU} . \mathrm{mL}^{-1}$ for bacteria and $1 \times 10^{6}$ CFU.mL ${ }^{-1}$ for yeast $C$. albicans.

\section{Minimum inhibitory concentration (MIC)}

The assays for the essential oil were carried out according to the broth microdilution methodology described by Weber et al. (2014). The 
essential oil was solubilized in methanol P.A. and diluted in $\mathrm{MH}$ broth to the bacterial strains and Roswell Park Memorial Institute broth (RPMI1640) to $C$. albicans. In 96-well microdilution plates, $150 \mu \mathrm{L}$ of MH broth or RPMI-1640 was dispensed. Serial dilutions of the essential oil were performed between concentrations of 7000 and 3.37 $\mu \mathrm{g} . \mathrm{mL}^{-1}$. Finally, $10 \mu \mathrm{L}$ of inoculum was added to each well and the plates were incubated at $36 \pm 0.1$ ${ }^{\circ} \mathrm{C}$ for $18-24 \mathrm{~h}$. As positive controls, we used commercial antibiotic gentamicin (200 mg.mL ${ }^{-1}$ ) and commercial antifungal nystatin $\left(200 \mathrm{mg} \cdot \mathrm{mL}^{-1}\right)$. As a negative control the inoculum was added to the MH broth, without the presence of the essential oil to prove the viability of the tested microorganism. The triphenyltetrazolium chloride (TTC) at $0.5 \%$ was also used as a colorimetric developer. The MIC was measured in triplicate, where it was possible to determine the lowest concentration of essential oil capable of inhibiting microbial growth.

\section{Minimum bactericidal concentration $(\mathrm{MBC})$ /minimum fungicidal concentration (MFC)}

The assay methodology of Weber et al. (2014) was performed with modifications. Before the addition of $0.5 \%$ TTC to determine the MIC, a 2 $\mu \mathrm{L}$ aliquot of each well of the microdilution plate was removed and plated on the $\mathrm{MH}$ agar surface. The plates were incubated at $36 \pm 0.1{ }^{\circ} \mathrm{C}$ for $18-24$ $\mathrm{h}$. The assay was performed in triplicate and to determine the MBC and MFC was observed if there was microbial growth in $\mathrm{MH}$ agar, allowing us to verify which was the lowest concentration of the essential oil capable of causing the death of the bacterium/fungus tested.

\section{Antioxidant activity}

The antioxidant activity of the essential oil was determined according to the method of reducing $\mathrm{DPPH}$, as proposed by Rufino et al. (2007). Initially, a calibration curve $(0,10,20,30,40,50$ and $60 \mu \mathrm{M}$ DPPH) was made to obtain the DPPH concentration in the medium after the reaction with the essential oil, with the equation $y=0.011 x-0.005\left(\mathrm{R}^{2}=\right.$ $0,999)$, where $y$ is the concentration of DPPH and $x$ is absorbance. For this, aliquots of $0.1 \mathrm{~mL}$ of essential oil at different concentrations $(10,20,30$, 40 and $50 \mathrm{mg} \cdot \mathrm{mL}^{-1}$ ) were added to $3.9 \mathrm{~mL}$ of methanolic DPPH solution $(60 \mathrm{mM})$ and homogenized in a shaker tube. As a negative control, $0.1 \mathrm{~mL}$ of a solution of $50 \%$ methanol, $70 \%$ acetone and distilled water in a ratio of 2:2:1 (v/v/v), and as a positive control, the synthetic antioxidant BHT (butyl-hydroxy-toluene), was used in different concentrations $(0.0312,0.062,0.125,0.25$ and 0.5 $\left.\mathrm{mg} \cdot \mathrm{mL}^{-1}\right)$. The tests were performed in a spectrophotometer at $515 \mathrm{~nm}$ for 1-min reading intervals until stabilization of absorbance. As a result of its white color, methanol was used for the calibration of the spectrophotometer. The percentage of free radical sequestration $(A A \%)$ was expressed by the equation: $A A \%=\left[A_{0}-A_{1} / A_{1}\right] X$ 100 where $A_{0}$ is the absorbance of the negative control and $A_{l}$ is the absorbance of the sample. For the calculation of $\mathrm{IC}_{50}$ (amount of antioxidant substance required to reduce the initial concentration of DPPH by 50\%), the concentrations of the essential oil and BHT were used to obtain the equation of the line with $\mathrm{R}^{2}$ greater than 0.80 , find the value of $\mathrm{IC}_{50}$, from linear regression. The tests were performed in triplicate and expressed as mean \pm standard deviation. The $\mathrm{IC}_{50}$ results were analyzed by the chi-square test of adhesion using the $R \AA$ statistical program ( $\mathrm{R}$ DEVELOPMENT CORE TEAM, 2017).

\section{RESULTS AND DISCUSSION}

\section{Chemical composition of essential oil of $E$. involucrata}

From the extraction of the essential oil from the leaves of E. involucrata, a total yield of $0.21 \%$ was observed. The chemical composition of the essential oil, together with its retention indices, is shown in Table 1. The GC-MS analysis identified 28 compounds, corresponding to $89.41 \%$ of the essential oil.

The analysis of chemical components of the essential oil of $E$. involucrata, demonstrated the presence of hydrocarbon and oxygenated sesquiterpenes in proportions of $83.05 \%$ and $6.36 \%$, respectively. The most abundant components in the sample were elixene (26.53\%), $\beta$-caryophyllene (13.16\%), $\alpha$-copaene $(8.41 \%)$ and germacrene D (7.17\%), all hydrocarbon sesquiterpenes.

In the family of Myrtaceae, the species of the genus Eugenia present as the predominant chemical compounds from the group of sesquiterpenes, and to a lesser extent, it is observed the compounds from the group of monoterpenes (CARNEIRO et al., 2017; HENRIQUES et al., 1993; MARIN, et al. 2008; RAMOS et al., 2006). However, in this species, no compounds belonging to the monoterpenes were found. 
Table 1. Chemical composition of the essential oil of E. involucrata leaves obtained by hydrodistillation and analyzed by GC-MS.

\begin{tabular}{llllll}
\hline $\mathbf{N}^{\mathbf{0}}$ & Compound & $\mathbf{A r e a}(\boldsymbol{\%})$ & $\mathbf{R T}$ & $\mathbf{R I}$ & $\mathbf{R I}^{*}$ \\
\hline 1 & -Elemene & 4.29 & 25.97 & 1331 & 1337 \\
2 & $\alpha$-Cubebene & 0.25 & 26.49 & 1343 & 1345 \\
3 & Cyclosativene & 0.21 & 27.43 & 1364 & 1367 \\
4 & $\alpha$-Copaene** & 8.41 & 27.74 & 1371 & 1376 \\
5 & $\beta$-Bourbonene & 0.42 & 28.07 & 1378 & 1381 \\
6 & $\beta$-Elemene & 4.95 & 28.35 & 1385 & 1390 \\
7 & $\alpha$-Gurjunene & 0.48 & 29.08 & 1401 & 1409 \\
8 & Caryophyllene** & 13.16 & 29.60 & 1414 & 1419 \\
9 & $\beta$-Gurjunene & 0.81 & 30.05 & 1424 & 1431 \\
10 & Aromadendrene & 0.70 & 30.38 & 1432 & 1440 \\
11 & $\alpha$-caryophyllene & 3.45 & 31.11 & 1449 & 1459 \\
12 & Allo-Aromadendrene & 2.82 & 31.29 & 1454 & 1465 \\
13 & $\gamma$-Muurolene & 1.04 & 31.97 & 1470 & 1476 \\
14 & Germacrene D** & 7.17 & 32.19 & 1475 & 1480 \\
15 & Elixene** & 26.53 & 32.80 & 1489 & $1492^{1}$ \\
16 & $\alpha$-Muurolene & 0.85 & 32.96 & 1493 & 1498 \\
17 & $\gamma$-Cadinene & 0.53 & 33.53 & 1507 & 1513 \\
18 & $\beta$-Cadinene & 6.00 & 33.75 & 1512 & 1518 \\
19 & 1,4-Cadinadiene & 0.06 & 34.31 & 1526 & 1528 \\
20 & $\alpha$-Cadinene & 0.11 & 34.48 & 1531 & 1533 \\
21 & $\alpha$-Calacorene & 0.11 & 34.64 & 1535 & 1540 \\
22 & Germacrene B & 0.70 & 35.32 & 1552 & 1551 \\
\hline Hydrocarbon sesquiterpenes & 83.05 & & & \\
\hline 23 & Spathulenol & 2.57 & 36.05 & 1570 & 1576 \\
24 & Caryophyllene oxide & 0.75 & 36.24 & 1575 & 1581 \\
25 & Globulol & 0.52 & 36.40 & 1579 & 1583 \\
26 & IsoSpathulenol & 1.85 & 38.06 & 1621 & 1628 \\
27 & $\tau$-Cadinol & 0.46 & 38.60 & 1635 & 1638 \\
28 & $\alpha$-Cadinol & 0.21 & 39.09 & 1648 & 1652 \\
\hline Oxygenated Sesquiterpenes & 6.36 & & & \\
\hline 29 & NI & 1.75 & 32.49 & 1482 & \\
30 & NI & 4.25 & 33.27 & 1500 & \\
31 & NI & 1.07 & 34.05 & 1520 & \\
\hline$N o n e$ & $7 n d e n t i f i e d$ & & & \\
\hline
\end{tabular}

None indentified 7.07

Total 96.48

RT: Retention time; RI: Values calculated retention indices; RI*: Retention index values from NIST/EPA/NIH Mass Spectral Library, version $2.0 \mathrm{~d}$, april 2005; **Manjority compounds; NI: Not identified

In the literature, the chemical constituents of the essential oil of leaf E. involucrata were identified by several authors. Ramos et al. (2006) found 27 chemical compounds, considering founds compounds in the majority: bicyclogermacrene (19\%), globulol (14\%), epi-globulol $(8 \%)$ and $\gamma$ elemene (7.2\%). Henriques et al. (1993) characterized $93.5 \%$ of the essential oil, with viridiflorene (36.2\%), $\beta$-caryophyllene $(23.1 \%)$ and germacrene D (6\%) as the major compounds. More recently, Ciarlini, Marangoni and Bolzan, (2017) detected $88.79 \%$ of the compounds present in the oil E. involucrata, the most abundant being $\beta$-elemene
(48.41\%), bicyclogermocrene (22.96\%), caryophyllene (13.94\%) and germacrene D (4.02\%).

Considering these previous studies, the presence of some compounds in common in the essential oils of E. involucrata was discovered, however, because it was a mixture, it was observed that the chemical profile differs in quantity, number of compounds and molecular configuration. This variation may be related to climatic factors (temperature, relative air humidity, exposure to ultraviolet radiation and wind regime), geographic location (altitude, habitat and air pollution), soil composition, plant organ, age and stage of the cycle 
vegetative, genetic diversity, seasonality, circadian rhythm, water availability, nutrients, protection against pathogens, among others (GOBBO-NETO; LOPES, 2007). Thus, research aimed at standardizing the chemical constituents of essential oils should be performed to verify the environmental influences on the metabolic production of these compounds and for their possible safe use by the market.
The results concerning the antimicrobial activity of the essential oil of the leaves of $E$. involucrata are described in Table 2 . The inhibitory and bactericidal effects of the oil were verified for all Gram-positive bacteria tested and for yeast $C$. albicans. MIC values ranged from $875-7000$ $\mu \mathrm{g} . \mathrm{mL}^{-1}$ and those from CBM from $1750-7000$ $\mu \mathrm{g} . \mathrm{mL}^{-1}$. The bacteria most susceptible to oil action were $S$. epidermidis and B. subtilis, with MICs of 875 and $\mathrm{CBM}$ of $1750 \mu \mathrm{g} \cdot \mathrm{mL}^{-1}$.

\section{Antimicrobian activity}

Table 2. Minimal inhibitory concentration (MIC), minimum bactericidal concentration/minimum fungicidal concentration (MBC/MFC) essential oil of E. involucrata against pathogenic microorganisms.

\begin{tabular}{lll}
\hline Microorganisms & $\begin{array}{l}\text { MIC } \\
\left(\boldsymbol{\mu g} \cdot \mathbf{m L}^{-1}\right)\end{array}$ & $\begin{array}{l}\text { MBC/MFC } \\
\left(\boldsymbol{\mu g} . \mathbf{m L} \mathbf{L}^{-1}\right)\end{array}$ \\
\hline Gram-positive & & 7000 \\
\hline S. aureus (ATCC 25923) & 875 & 1750 \\
S. epidermidis (ATCC 12228) & 875 & 7000 \\
E. faecalis (ATCC 19433) & 7000 & 1750 \\
B. subtilis (CCCD B005) & 875 & - \\
\hline Gram-negative & & - \\
\hline S. Typhimurium (ATCC 14028) & - & - \\
S. Enteritidis (ATCC 13076) & - & - \\
E. coli (ATCC 25922) & - & - \\
K. pneumoniae (ATCC 13883) & - & - \\
$P$. mirabilis (ATCC 25933), & - & \\
P. aeruginosa (ATTC 27853) & - & 3500 \\
\hline Yeast & & \\
\hline C. albicans (ATCC 10231) & 1750 & \\
\hline
\end{tabular}

(-) No activity

Due to the unique characteristics of the essential oils, it is believed that the antimicrobial activity of the oils is attributed to several cellular mechanisms. The hydrophobic profile of the compounds present in the oil is the main characteristic that proves its antimicrobial potential. Its role in irreversibly disrupting microbial cell membrane lipids makes the membrane permeable and promotes the loss of internal cellular content (ions, glucose and ATP), leading to the death of the microorganism. In addition, the oils can also alter the enzymatic systems involving energy production and the synthesis of structural compounds (BURT, 2004; DJILANI; DICKO, 2012).

Although no reports of the antimicrobial activity of E. involucrata essential oil were found in the literature, many species with antimicrobial properties were observed within the genus Eugenia. Stefanello et al. (2008) tested the essential oil of the leaves of Eugenia chlorophylla, proving its antimicrobial properties against $S$. aureus (MIC $=1000 \mu \mathrm{g} \cdot \mathrm{mL}^{-1}$ ). Lago et al. (2011) reported the antimicrobial potential of Eugenia uniflora essential oil against $S$. epidermidis (MIC $=7500$ $\mu \mathrm{g} . \mathrm{mL}^{-1}$ ). Ogunwande et al. (2005) demonstrated the inhibitory effect of $E$. uniflora essential oil for Gram-positive B. cereus (MIC $=39 \mu \mathrm{g} \cdot \mathrm{mL}^{-1}$ ) and $S$. aureus (MIC $=156 \mu \mathrm{g} \cdot \mathrm{mL}^{-1}$ ) and Gram-negative $P$. aeruginosa $\quad\left(\mathrm{MIC}=625 \mu \mathrm{g} \cdot \mathrm{mL}^{-1}\right)$ and $E$. coli $\left(\mathrm{MIC}=625 \mu \mathrm{g} \cdot \mathrm{mL}^{-1}\right)$ at significantly low concentrations.

It is observed that in most studies on the action of essential oils, Gram-positive bacteria are more susceptible than Gram-negative bacteria (BURT, 2004; LAGO et al., 2011; STEFANELLO et al., 2008). According to the literature, Grampositive strains are more susceptible to Gramnegative strains ( $S$. Typhimurium, $S$. Enteretidis, $E$. coli, $K$. pneumoniae, $P$. mirabilis and $P$. aeruginosa), which were resistant to the oil concentrations tested.

One of the explanations for this fact is related to the presence of an outer phospholipid membrane that surrounds the Gram-negative cell wall. This membrane contains hydrophilic lipopolysaccharides that act as a barrier to 
Chemical composition...

macromolecules and hydrophobic compounds, thus providing greater tolerance to some antimicrobial compounds, such as those found in essential oils (PANDEY et al., 2016). In addition, the periplasmic space contains enzymes capable of breaking molecules and the membrane contains efflux pumps capable of removing compounds considered harmful to the bacterial cell (BURT, 2004; TADEG et al., 2005). Therefore, as Gram-positive bacteria do not contain this additional barrier, although they present a cell wall with greater thickness, it is not as complex, being composed of lipophilic ends of lipoteichoic acids, which facilitates the direct contact of the essential oil with the bacterial cell (TONGNUANCHAN; SOOTTAWAT, 2014).

As in our study, some authors have proved the antifungal potential of Eugenia species. Stefanello et al. (2008) tested the essential oil of $E$. chlorophylla, proving its antifungal properties of $C$. albicans, with a MIC of $500 \mu \mathrm{g} \cdot \mathrm{mL}^{-1}$. This was also observed by Lago et al. (2011), who in his study demonstrated the inhibition of $C$. albicans by the essential oil of $E$. uniflora in the concentration of $1800 \mu \mathrm{g} \cdot \mathrm{mL}^{-1}$.

The antifungal action found in many essential oils is related to the presence of sesquiterpenes. Since the oil has lipophilic characteristics, this allows it to penetrate the fungal cell wall, interfering with the action of enzymes involved in its synthesis, and also to establish a $\mathrm{pH}$ gradient through the cytoplasmic membrane and block energy production, causing membrane changes and changing the fungus morphology (DJILANI; DICKO, 2012; PANDEY et al., 2016).
TOLEDO, A. G. et al.

The antimicrobial potential of the essential oil of E. involucrata can be attributed almost exclusively to the major components present, such as $\beta$-caryophyllene (AL-BAYATI, 2008), germacreno D (JIMÉNEZ et al., 2012), $\alpha$-copaene (LIN; DOU; XU, 2012) and elixene (YU et al., 2007). However, because it is a complex mixture, the synergistic, antagonistic or additive interaction between the essential oil compounds must also be considered, as well as studies with isolated compounds, to verify if there is any influence of the compounds present in smaller quantities in the potential antimicrobial properties of this essential oil (BURT, 2004).

\section{Antioxidant activity}

The antioxidant capacity of the essential oil of the leaves of E. involucrata was determined by decreasing the absorbance at $515 \mathrm{~nm}$ using the DPPH sequestration assay (Tables 3 and 4). The elimination of the free radicals by the essential oil was dependent on the concentrations, with the most expressive result in the highest concentration tested $\left(50 \mathrm{mg} \cdot \mathrm{mL}^{-1}\right)$, with an antioxidant potential of $66.81 \%$ and an $\mathrm{IC}_{50}$ value of $38.61 \pm 1.11 \mathrm{mg} \cdot \mathrm{mL}^{-1}$. This value of $\mathrm{IC}_{50}$ was considered statistically different from the value found for the synthetic antioxidant BHT, with an $\mathrm{IC}_{50}$ of $0.094 \pm 0.01 \mathrm{mg} \cdot \mathrm{mL}^{-1}$ (Test $\chi 2=38.329$; GL $=1 ; \mathrm{p}<0.05)$, which demonstrates the need for a higher concentration of essential oil to sequester the same amount of DPPH radicals as compared to BHT.

Table 3. Percentage of antioxidant activity of the essential oil of the leaves of E. involucrata by the DPPH method.

\begin{tabular}{lllllllllll}
\hline Sample & \multicolumn{8}{c}{ Concentration $\left(\mathbf{m g}^{\prime} \mathbf{m L}^{-\mathbf{1}}\right)$} \\
& 0,0312 & 0,0625 & 0,125 & 0,250 & 0,500 & 10 & 20 & 30 & 40 & 50 \\
\hline Essential & - & - & - & - & - & $14,91 \pm 0$ & $25 \pm 0$, & $35,96 \pm$ & $51 \pm 1$, & $66,81 \pm 2$ \\
oil & & & & & &, 33 & 66 & 1,6 & 19 &, 16 \\
BHT & $25,03 \pm$ & $42,1 \pm 1$, & $67,28 \pm 1$ & $88,62 \pm 0$ & $94,59 \pm 0$ & - & - & - & - & \\
& 1,88 & 49 &, 64 &, 45 &, 41 & & & & & \\
\hline
\end{tabular}

(-) Not tested; BHT (commercial synthetic antioxidant Butylhydroxytoluene); Percentage of DPPH radical sequestration was expressed as mean \pm standard deviation.

Table 4. Value of $\mathrm{IC}_{50}$ of the essential oil of the leaves of E. involucrata by the DPPH method.

\begin{tabular}{lc}
\hline Sample & IC $_{\mathbf{5 0}}\left(\mathbf{m g} \cdot \mathbf{m L}^{\mathbf{- 1}}\right)$ \\
\hline Essential oil & $38,61 \pm 1,11$ \\
BHT & $0,094 \pm 0,01$ \\
\hline BHT (commercial synthetic antioxidant Butylhydroxytoluene); Values of $\mathrm{IC}_{50}$ (Concentration of E. involucrata leaves extract is \\
necessary to reduce 50\% of the DPPH radical) expressed as mean \pm standard deviation; Different letters in the same column express \\
significant differences (p <0.05); Equation (Allows to estimate expected value of variable y, given the values of variable x); $\mathrm{R}^{2}$ \\
(Coefficient of determination of a linear statistical model that explains the percentage of relation of observed values).
\end{tabular}


It is suggested that the antioxidant activity of the E. involucrata essential oil is attributed mainly to its major components: elixene, $\beta$ caryophyllene, $\alpha$-copaene and germacrene $D$, and the potential of $\beta$-caryophyllene and germacrene $D$, as excellent antioxidants (CARNEIRO et al., 2017; HEMALATHA et al., 2015). Generally, the potential of the essential oils corresponds to the phenolic content. However, some essential oils have antioxidant behavior according to the chemical structure of their components, as is the case for some terpenes (AMORATI; FOTI; VALGIMIGLI, 2013; PANIGRAHY; KUMAR; BHATT, 2017).

Recent studies on the antioxidant activity of the essential oils of $E$. involucrata leaves demonstrated an antioxidant potential of $6.41 \%$ using the methodology of $\beta$-carotene/linoleic acid (CIARLINI; MARANGONI; BOLZAN, 2017), that is, an activity about 10 times lower than that found in this study. According to the authors, different techniques for the extraction of volatile compounds may reflect the antioxidant potential of the species.

Although few studies exist focusing on the leaves of $E$. involucrata, the fruit was much researched as to its antioxidant potential, due to its use in the form of juices, liqueurs and jellies (LORENZI, 2009). Marin et al. (2008), Infante et al. (2016) and Nicácio et al (2017) confirmed the antioxidant potential of E. involucrata. In addition, Carneiro et al. (2017) and Infante et al. (2016) evidenced antioxidant activity in the essential oils of four other species: Eugenia klotzschiana, Eugenia brasiliensis, Eugenia myrcianthes and Eugenia leitonii, thus demonstrating the potential of this genus.

Finally, it is suggested that studies related to the method of collection, drying and extraction of essential oil may contribute to further clarification regarding its antioxidant action, since these factors directly influence the active principles that make up the essential oil (GOBBO-NETO; LOPES, 2007; CIARLINI; MARANGONI; BOLZAN, 2017).

\section{CONCLUSIONS}

In the characterization of essential oil of $E$. involucrata, 28 compounds were identified, all sesquiterpenes. The compounds found in most of the sample were elixene $(26.53 \%), \beta$-caryophyllene (13.16\%), $\alpha$-copaene $(8.41 \%)$ and germacrene D (7.17\%), very common within this genus, inferring the antimicrobial and antioxidant potential of the essential oil.

The essential oil of E. involucrata leaves presented antimicrobial activity for all Grampositive bacteria (S. epidermidis, E. faecalis, $B$. subtilis and $S$. aureus) and for yeast $C$. albicans. Their ability to sequester free radicals was also reported, demonstrating antioxidant activity of up to $66.81 \%$.

It is hoped that these results will contribute to further clarification of the biological potential of this essential oil, allowing future scientific validation research to provide subsidies for plant bioengineering to make possible the international standardization of the compounds present in essential oils, optimizing its potential for biological and commercial applications.

\section{ACKNOWLEDGEMENTS}

The first author thanks the Coordination of Improvement of Higher Education Personnel CAPES (government body linked to the Brazilian Ministry of Education charged with promoting high standards of postgraduate studies in Brazil) for the grant awarded for the study; and to the Herbarium of the State University of the West of Paraná (UNOP) for the botanical identification.

RESUMO: Na família Myrtaceae, a espécie Eugenia involucrata DC. popularmente denominada "cerejeira-do-mato" é conhecida tradicionalmente pela ação antidiarreica e digestiva de suas folhas. Contudo, na literatura não foram encontrados trabalhos referentes ao seu potencial antimicrobiano e antioxidante. Neste contexto, o objetivo do presente estudo foi determinar a composição química por cromatografia gasosa acoplada a espectrometria de massas (CG-EM) e avaliar a atividade antimicrobiana pela técnica de microdiluição em caldo e a atividade antioxidante pelo método do 2,2-difenil-1-picril-hidrazila (DPPH) do óleo essencial das folhas de E. involucrata. A CG-EM identificou 28 compostos, todos sesquiterpenos, correspondendo a $89,41 \%$ do óleo essencial. A atividade antimicrobiana do óleo essencial foi observada para todas as bactérias Gram-positivas testadas (Staplylococcus epidermidis, Enterococcus faecalis, Bacillus subtilis e Staplylococcus aureus) e para a levedura Candida albicans. O óleo essencial apresentou capacidade redutora de radicais DPPH de até $66,81 \%$, evidenciando sua potencialidade antioxidante. Sugere-se que a ação antimicrobiana e antioxidante do óleo essencial de $E$. involucrata esteja relacionada à presença dos compostos majoritários, elixeno (26,53\%), $\beta$-cariofileno $(13,16 \%)$, $\square$-copaeno $(8,41 \%)$ e germacreno $\mathrm{D}(7,17 \%)$. 
PALAVRAS-CHAVE: Myrtaceae. Produtos naturais. Compostos voláteis. Hidrodestilação. Atividades biológicas. CG-EM.

\section{REFERENCES}

ADAMS, R. P. Identification of essential oil components by Gas Chromatography/Mass Spectrometry. Illinois USA: Allured Publishing Corporation, Carol Stream, 2007.

AL-BAYATI, F. A. Synergistic antibacterial activity between Thymus vulgaris and Pimpinella anisum essential oils and methanol extracts. J. Ethnopharmacol., v. 116, p. 403-406, 2008.

https://doi.org/10.1016/j.jep.2007.12.003

AMORATI, R; FOTI, M. C.; VALGIMIGLI, L. Antioxidant activity of essential oils. J. Agric. Food Chem., v. 61, p. 10835-10847, 2013. https://doi.org/10.1021/jf403496k

BABUSHOK, V. I.; LINSTROM, P. J.; ZENKEVICHB, I. G. Retention indices for frequently reported compounds of plant essential oils. J. Phys. Chem. Ref. Data, v. 40, p. 043101-043147, 2011.

https://doi.org/10.1365/s10337-008-0872-3

BURT, S. Essential oils: their antibacterial properties and potential applications in foods - a review. Int. J. Food Microbiol., v. 94, p. 223-253, 2004. https://doi.org/10.1016/j.ijfoodmicro.2004.03.022

CARNEIRO, N. S.; ALVES, C. C. F.; ALVES, J. M.; EGEA, M. B.; MARTINS, C. H. G.; SILVA, T. S.; BRETANHA, L. C.; BALLESTE, M. P.; MICKE, G. A.; SILVEIRA, E. V.; MIRANDA, M. L. D. Chemical composition, antioxidant and antibacterial activities of essential oils from leaves and flowers of Eugenia klotzschiana Berg (Myrtaceae). An. Acad. Bras. Cienc., v. 89, p. 1907-1915, 2017.

https://doi.org/10.1590/0001-3765201720160652

CIARLINI, J. J. S.; MARANGONI, A.; BOLZAN, A. Selectivity of supercritical $\mathrm{CO}_{2}$ extraction and atmospheric pressure techniques for the major volatile compounds of Eugenia involucrata leaves from Southern Brazil. Food Bioprod. Process., v. 106, p. 29-34, 2017. https://doi.org/10.1016/j.fbp.2017.08.008

DJILANI, A.; DICKO, A. The Therapeutic Benefits of Essential Oils. Nutrition, In: Bouayed J (Ed.) Nutrition, well-being and health, InTech, pp. 155-178, 2012. Disponível em:

<http://www.intechopen.com/books/nutrition-well-being-and-health/the-therapeutic-benefits-of-essential-oils>. Acesso em: 06 nov. 2018. https://doi.org/10.5772/25344

FRUTUOSO, A. E.; NASCIMENTO, N. T.; LEMOS, T. L. G.; COELHO, E. L.; TEIXEIRA, D. M. A. Essential oils applied in food: a review. Brazilian Journal of Food Research, v. 4, p. 69-81, 2013. https://doi.org/10.14685/rebrapa.v4i2.134

GOBBO-NETO, L.; LOPES, N. P. Medicinal plants: factors of influence on the content of secondary metabolites. Quim. Nova, v. 30, p. 374-381, 2007. https://doi.org/10.1590/S0100-40422007000200026

HAJOORI, M.; NAIK, M.; NAIK, K.; BUTANI, N. Evaluation of antimicrobial activity of Eugenia jambolana seed extract against human pathogens. Int. J. Pharm. Chem. Biol. Sci., v. 3, p. 935-939, 2013.

HEMALATHA, R.; NIVETHA, P.; MOHANAPRIYA, C.; SHARMILA, G.; MUTHUKUMARAN, C.; GOPINATH, M. Phytochemical composition, GC-MS analysis, in vitro antioxidant and antibacterial potential of clove flower bud (Eugenia caryophyllus) methanolic extract. J. Food Sci. Technol., v. 53, p. 1189-1198, 2015. https://doi.org/10.1007/s13197-015-2108-5 
HENRIQUES, A. T.; SOBRAL, M. E.; CAUDURRO, A. D.; SCHAPOVAL, E. E. S.; BASSANI, V. L.; LAMATY, G.; MENUT, G.; BESSIÈRRE, J. M. Aromatic plants from Brazil. II. The chemical composition of some Eugenia essential oils. J. Essent. Oil Res., v. 5, p. 501-505, 1993.

https://doi.org/10.1080/10412905.1993.9698270

INFANTE, J.; ROSALEN, P. L.; LAZARINI, J. G.; FRANCHIN, M.; ALENCAR, S. M. Antioxidant and antiinflammatory activities of unexplored brazilian native fruits. PLoS ONE, v. 11, p. e0152974, 2016. https://doi.org/10.1371/journal.pone.0152974

JIMÉNEZ, D.; ARAQUE, M.; ROJAS, L.; CORDERO, A.; BRICEÑO, B. Volatile components and antibacterial activity from Myrcia splendens (Sw.) DC. shoots. Rev. Fac. Farm., v. 54, p. 7-11, 2012.

LAGO, J. H.; SOUZA, E. D.; MARIANE, B.; PASCON, R.; VALLIM, M. A.; MARTINS, R. C.; BAROLI, A. A.; CARVALHO, B. A.; SOARES, M. G.; SANTOS, R. T.; SARTORELLI, P. Chemical and biological evaluation of essential oils from two species of myrtaceae - Eugenia uniflora L. and Plinia trunciflora (O. Berg) Kausel. Molecules, v. 16, p. 9827-9837, 2011. https://doi.org/10.3390/molecules16129827

LIN, J.; DOU, J.; XU, J. Chemical composition, antimicrobial and antitumor activities of the essential oils and crude extracts of Euphorbia macrorrhiza. Molecules, v. 17, p. 5030-5039, 2012. https://doi.org/10.3390/molecules 17055030

LORENZI, H. Árvores brasileiras: manual de identificação e cultivo de plantas arbóreas nativas do Brasil. Nova Odessa: Instituto Plantarum, 2009. https://doi.org/10.1590/S0100-39842009000300014

MARIN, R.; APEL, M. A.; LIMBERGER, R. P.; RASEIRA, M. C. B.; PEREIRA, J. F. M.; ZUANAZZI, J. Â. S.; HENRIQUES, A. T. Volatile components and antioxidant activity from some Myrtaceous fruits cultivated in Southern Brazil. Lat. Am. J. Pharm., v. 27, p. 172-177, 2008.

NICÁCIO, A. E.; ROTTA, E. M.; BOEING, J. S.; BARIZÃO, E. O.; KIMURA, E.; VISENTAINER, J. V.; MALDANER, L. Antioxidant activity and determination of phenolic compounds from Eugenia involucrata DC. fruits by UHPLC-MS/MS. Food Anal. Methods, v. 10, p. 2718-2728, 2017.

https://doi.org/10.1007/s12161-017-0840-3

OGUNWANDE, I. A.; OLAWORE, N. O.; EKUNDAYO, O.; WALKER, T. M.; SCHMIDT, J. M.; SETZER, W. N. Studies on the essential oils composition, antibacterial and cytotoxicity of Eugenia uniflora L. Int. J. Aromather., v. 15, p. 147-152, 2005. https://doi.org/10.1016/j.ijat.2005.07.004

PANDEY, A. K.; KUMAR, P.; SINGH, P.; TRIPATHI, N. N.; BAJPAI, V. K. Essential oils: sources of antimicrobials and food preservatives. Front. Microbiol., v. 7, p. 2161, 2016.

https://doi.org/10.3389/fmicb.2016.02161

PANIGRAHY, S. K.; KUMAR, A.; BHATT, R. Antioxidant potentials of successive solvent extracts from the unexplored Hedhychium coronarium rhizome. J. Food Sci. Technol., v. 54, p. 3297-3306, 2017.

https://doi.org/10.1007/s13197-017-2777-3

R DEVELOPMENT CORE TEAM. R: a language and environment for statistical, Vienna, 2017.

RAMOS, M. F. S.; SIANI, A. C.; SOUZA, M. C.; ROSAS, E. C.; HENRIQUES, M. G. M. O. Evaluation of the anti-inflammatory activity of evaluation of the anti-inflammatory activity of essential oils from five myrtaceae species. Rev. Fitos, v. 2, p. 58-66, 2006.

RUFINO, M. S. M.; ALVES, R. E.; BRITO, E. S.; MORAIS, S. M.; SAMPAIO, C. G.; JIMENEZ, J. P.; CALIXTO, F. D. S. Determination of total antioxidant activity in fruits by the capture of free radical DPPH. Embrapa Agroindústria Tropical, Comunicado técnico 127, 1-4, 2007. 
SANTOS, M. I. S.; MARTINS, S. R.; VERÍSSIMO, C. S. C.; NUNES, M. J. C.; LIMA, A. I. G.; FERREIRA, R. M. S. D.; PEDROSO, L.; SOUSA, I.; FERREIRA, M. A. S. S. Essential oils as antibacterial agents against food-borne pathogens: are they really as useful as they are claimed to be? J. Food Sci. Technol., v. 54, p. 4344-4352, 2017. https://doi.org/10.1007/s13197-017-2905-0

SAUSEN, T. L.; LÖWE, T. R.; FIGUEIREDO, L. S.; BUZATTO, C. R. Avaliação da atividade alelopática do extrato aquoso de folhas de E. involucrata e A. sellowiana. Polibotânica, v. 27, p. 145-158, 2009.

SILVA, N. C. C.; FERNANDES JÚNIOR, A. Biological properties of medicinal plants: a review of their antimicrobial activity. J. Venom. Anim. Toxins Incl. Trop. Dis., v. 16, p. 402-413, 2010. https://doi.org/10.1590/S1678-91992010000300006

SILVESTRI, J. D. F.; PAROUL, N.; CZYEWSKI, E.; LERIN, L.; ROTAVA, I.; CANSIAN, R. L.; MOSSI, A.; TONIAZZO, G.; OLIVEIRA, D.; TREICHEL, H. Chemical composition and antioxidant and antibacterial activities of clove essential oil (Eugenia caryophyllata Thunb). Rev. Ceres, v. 57, p. 589-594, 2010. https://doi.org/10.1590/S0034-737X2010000500004

STEFANELLO, M. E. A.; CERVI, A. C.; ITO, I. Y.; SALVADOR, M. J.; WISNIEWSKI, A. J.; SIMIONATTO, E. L. Chemical composition and antimicrobial activity of essential oils of Eugenia chlorophylla (Myrtaceae). J. Essent. Oil Res., v. 20, p. 75-78, 2008.

https://doi.org/10.1080/10412905.2008.9699427

TADEG, H.; MOHAMMED, E.; ASRES, K.; GEBRE-MARIAM, T. Antimicrobial activities of some selected traditional Ethiopian medicinal plants used in the treatment of skin disorders. J. Ethnopharmacol., v. 100, p. 168-175, 2005. https://doi.org/10.1016/j.jep.2005.02.031

TONGNUANCHAN, P.; BENJAKUL, S. Essential oils: extraction, bioactivities, and their uses for food preservation. J. Food Sci., v. 79, p. 1231-1249, 2014. https://doi.org/10.1111/1750-3841.12492

WEBER, L. D.; PINTO, F. G. S.; SCUR, M. C.; SOUZA, J. G. L.; COSTA, W. F.; LEITE, C. W. Chemical composition and antimicrobial and antioxidant activity of essential oil and various plant extracts from Prunus myrtifolia (L.) Urb. Afr. J. Agric. Res., v. 9, p. 846-853, 2014. https://doi.org/10.5897/AJAR2013.8260

YU, J. Q.; LIAO, Z. X.; CAI, X. Q.; LEI, J. C.; ZOU, G. L. Composition, antimicrobial activity and cytotoxicity of essential oils from Aristolochia mollissima. Environ. Toxicol. Pharmacol., v. 23, p. 162-167, 2007. https://doi.org/10.1016/j.etap.2006.08.004 